\title{
Erratum to: Articles by A.H. Clifford
}

\section{Michael Mislove}

Received: 27 March 2013 / Published online: 6 June 2013

(C) Springer Science+Business Media New York 2013

\section{Erratum to: Semigroup Forum (1996) 52:3-6 \\ DOI 10.1007/BF02574076}

This is a correction to Articles by A.H. Clifford which appeared as Semigroup Forum 52, Issue 1(1996), pp. 3-6. The article listed below inadvertently was left off of the list of A.H. Clifford's publications. The editors regret the error.

A. H. Clifford and Mario Petrich, Some classes of completely regular semigroups, Journal of Algebra 46 (1977), pp. 462-480.

Communicated by Michael W. Mislove.

The online version of the original article can be found under doi:10.1007/BF02574076.

M. Mislove $(\bowtie)$

Department of Mathematics, Tulane University, New Orleans, LA 70118, USA

e-mail: mislove@tulane.edu 